rich in ammonia. The guano dust is carried by the prevailing west winds far into the country, and would fall into the mother-liquor lakes, where, on exposure to the air at a warm temperature, it would gradually oxidize to nitrate, and, acting on the sodium carbonate, would form sodium nitrate (Chili saltpetre).

The "caliche" (crude saltpetre) is most variable in appearance and in the percentage of nitrate which it contains. The various substances, other than sodium nitrate, which are found in the Tarapaca and Atacama deposits are described at length by the author, who compares them with those which are found at Stassfurt, and he traces in the comparative prominence of the more soluble salts in the Chilian deposits a further confirmation of his theory that the nitre-beds are formed from mother liquor salts.

The book is well indexed, and is supplied with a map and several sections of the district described.

\section{J. I. W.}

\section{OUR BOOK SHELF.}

Tenerife, and its Six Satcllites. By Olivia M. Stone. In Two Vols. (London: Marcus Ward, I 887.)

A GOOD book on the Canary Islands, which have been of so much service to many an invalid, has long been wanted ; for, as Mrs. Stone says, many parts even of the best-known islands of Tenerife and Gran Canaria are untrodden ground to English people, and are but little known to persons of any other nationality. Mrs. Stone supplies all the information that can be needed by the most exacting visitor to the islands, or by persons who may wish to read about them at home. As she has already shown in her "Norway in June," she has excellent powers of observation, and knows how to give a clear and effective account of all that she sees in her travels. In the present work her descriptions are all the more vivid because they were written "on the spot," when everything she wished to set down in her narrative was still fresh in her mind. To the Island of Hierro, to which she and her husband seem to have been the first English visitors, she devotes a good deal of attention; and what she has to say about that "solitary, happy, singular" island is full of interest, and would alone have justified her, if justification had been necessary, in making her travels in the Canary Islands the subject of a book. In an appendix she presents a useful epitome of all necessary expenses connected with her tour.

Through Central Asia. By Henry Lansdell, D.D. (London: Sampson Low, I887.)

THIS is a popular edition of the author's well-known "Russian Central Asia, including Kuldja, Bokhara, Khiva, and Merv." He has omitted many whole chapters and most of the notes, thinking it best that the present edition should consist chiefly of a personal narrative. Any student who may desire fuller information regarding Central Asia is referred to the original work, in which Dr. Lansdell gives 4300 species of fauna and flora in about twenty lists with introductions, adds a bibliography of 700 titles, and treats more or less fully of the geography, economy and administration, ethnology, antiquities, history, meteorology, geology, zoology, and botany of all parts of Russian Turkistan, Kuldja, Bokhara, Khiva, and Turkmenia, down to the frontier of Afghanistan. To the new and abridged edition he has added an appendix on he delimitation of the Russo-Afghan frontier.

\section{LETTERS TO THE EDITOR.}

[The Editor does not hold himself responsible for opinions expressed by his correspondents. Neither can he undertake to return, or to correspond with the writers of, rejected manuscripts. No notice is taken of anonymous communications.

[The Editor urgently requests correspondents to keep their letters as short as possible. The pressure on his space is so great that it is impossible otherwise to insure the appearance even of communications containing interesting and novel facts.

\section{The Star of Bethlehem.}

REFERRING to the hypothesis in your last week's issue, that the star of Bethlehem was Venus, I would point out that II 80 synodical periods of Venus (i.e. I I $80 \times 583^{\circ} .92=689,025$ mean solar days) take us back from October 28, I887--when Venus was at her maximum brilliancy as a morning star-to only May 3 of the year I A.D. instead of December 25 of the year I B.c. For the number of days from October 28 , I 887 , to December $25, \mathrm{I}$ B.C., is 689,155 (viz. $1887 \times 365^{\circ} 2425=689,213$ $-64+6=689,155)$. This would appear to show, either that the birth of Christ took place about May 3, or that Venus at her maximum brilliancy as a morning star was not the star of Bethlehem. I should be glad of your remarks on this. JOHN T. NICOLSON.

20 Thirlestane Road, Edinburgh, December 26, 1887.

I INFER from the article entitled "The Star of Bethlehem" (NATURE, December 22, 1887, p. I69) that the writer supposes the craze he deals with did not exist until Venus became a morning star. It was equally prevalent here when, early in the year, she was an evening star, as the following fact will show. On May 21, 1887, a lady wrote me as follows:- "Will you kindly tell me what people mean about ' $a$ zoonderful star'? All our servants are talking about it. . . . Some call it 'the star of Bethlehem.' . . . I hear it is 'wonderfully bright!" "

Torquay, December $26,1887$.

W. Pengelly.

IN regard to the so-called "star of Bethlehem," Prof. C. A. Grimmer, in "Life from the Dead," No. 69 (August 1879), p. 267 , wrote :- “It will be seen in 'Cassiopeia's Chair,' and will be accompanied by a total eclipse of the sun and moon. The marvellous brilliancy of the 'star of Bethlehem' in 1887 will surpass any of its previous visitations. It will be seen even at noonday, shining with a quick flashing light the entire year, after which it will gradually decrease in brightness, and finally disappear."

January 2.

\section{On some Apparent Contradictions at the Foundations} of Knowledge.

IN Chapter III. of Mr. Herbert Spencer's "First Principles" (p. 47, under heading, "Ultimate Scientific Ideas"), are treated the subjects of space and time. Here contradictions and diffculties of an apparently insuperable character are encountered in the attempt to define the nature of space and time, and the existence of these difficulties is frankly acknowledged. But with all the respect that is here due, it appears difficult to admit that these apparent contradictions are necessary, and in regard to space, in the first place, it will be my object here to suggest a remedy.

I will first quote some passages from the "First Principles" (5th edition) relating to this question, viz. as follows:-

"Thus as space and time connot either be nonentities, nor the attributes of entities, we have no choice but to consider them as entities. But while on the hypothesis of their objectivity, space and time must be classed as things, we find on experiment that to represent them in thought as things is impossible" (p. 47).

It will be observed here that we encounter the apparent contradiction that those are classed as things which it is found impossible to represent in thought as things. ${ }^{2}$

$x$ Experiment wo: 11 t'ien in irectly say that srace an 1 time were not things. 